\title{
Erratum to: Opportunities and challenges for mainstreaming ecosystem services in development planning: perspectives from a landscape level
}

\author{
Nadia Sitas · Heidi E. Prozesky • Karen J. Esler • \\ Belinda Reyers
}

Published online: 19 December 2013

(C) Springer Science+Business Media Dordrecht 2013

\section{Erratum to: Landscape Ecol DOI 10.1007/s10980-013-9952-3}

The original publication of the article includes a reference error that occurred during typesetting.

The correct reference and the citation are given below:

The reference "Wilhelm-Rechman et al. 2008" cited throughout the article is incorrect and should be
"Cowling et al. 2008" in the text. The full citation in the reference list should be as follows: Cowling RM, Egoh B, Knight AT, O'Farrell PJ, Reyers B, Rouget M, Roux DJ, Welz A, Wilhelm-Rechman A (2008) An operational model for mainstreaming ecosystem services for implementation. Proc Natl Acad Sci USA 105(28):9483-9488.

The online version of the original article can be found under doi: 10.1007/s10980-013-9952-3.

N. Sitas $(\bowtie) \cdot$ K. J. Esler · B. Reyers

Department of Conservation Ecology and Entomology,

Stellenbosch University, Private Bag X1, Matieland 7602,

South Africa

e-mail: nsitas@csir.co.za

H. E. Prozesky

Department of Sociology and Social Anthropology,

Stellenbosch University, Private Bag X1, Matieland 7602,

South Africa

H. E. Prozesky · K. J. Esler

Centre for Invasion Biology, Stellenbosch University,

Private Bag X1, Matieland 7602, South Africa

B. Reyers

Natural Resources and the Environment, Council for Scientific and Industrial Research, PO Box 320,

Stellenbosch, South Africa 